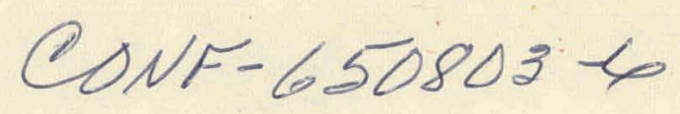

\title{
METHODS FOR THE DETERMINATION OF PLUTONIUM \\ IN SPENT REACTOR FUELS, PLUTONIUM METAL, ALLOYS AND COMPOUNDS \\ by

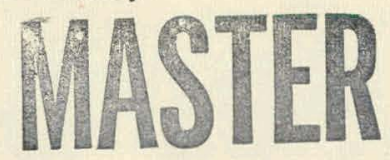

Charles F. Metz and Glenn R. Waterbury Group Leader and Assistant Group Leader for Chemical and Instrumental Analysis

The University of California Los Alamos Scientific Laboratory, Los Alamos, New Mexico, U. S. A.

\section{Introduction}

The successful management, or control, of such valuable and hazardous nuclear material as plutonium must rely heavily on methods of analysis of various process solutions arising during the separation of plutonium from irradiated reactor fuel, and also analysis of the final separated product. All subsequent work with plutonium, either research or manufacturing activities, likewise must rely heavily on methods of analysis for plutonium, its alloys and compounds.

This paper deals with those methods of analysis currently in use in the United States in the production of plutonium and also some of those used in the research and developmental programs involving plutonium metal, its alloys and compounds. Most of these methods have been developed in the United States. Alloted space did not permit complete coverage of all methods of analysis involving plutonium. However, an attempt was made to include those most widely used. No attempt has been made to give adequate coverage to those analytical methods that originated outside of the United States. It is hoped some of these will be discussed in other papers to be included in this conference.

\section{APPROVED FOR PUBLIC RELEASE}




\section{DISCLAIMER}

This report was prepared as an account of work sponsored by an agency of the United States Government. Neither the United States Government nor any agency Thereof, nor any of their employees, makes any warranty, express or implied, or assumes any legal liability or responsibility for the accuracy, completeness, or usefulness of any information, apparatus, product, or process disclosed, or represents that its use would not infringe privately owned rights. Reference herein to any specific commercial product, process, or service by trade name, trademark, manufacturer, or otherwise does not necessarily constitute or imply its endorsement, recommendation, or favoring by the United States Government or any agency thereof. The views and opinions of authors expressed herein do not necessarily state or reflect those of the United States Government or any agency thereof. 


\section{DISCLAIMER}

Portions of this document may be illegible in electronic image products. Images are produced from the best available original document. 
LEGAL NOTICE This report was prepared as an account of Government sponsored work. Netther the United A. Makes any warranty or representation, oppressed or implied wission racy, completeness, or usetuiness of the information contalned in this report, or that the use of any information, apparatus, method, or process disclosed in thls report may not infringe privately owned rights; or

B. Assumes any liabilities with respect to the use of, or for damages resulting from the Be of any informatton, apparatus, method, or process disclosed in this report.

ployee or contractor of the Commlssion, or employee of such contractor, to the extent that

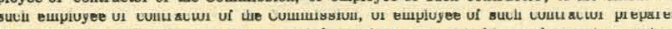

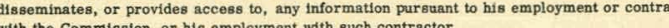




\section{Control analysis in plutonium production}

The two United States processes currently in use for the recovery of plutonium from irradiated production reactor fuels are known as Redox [2 37 and Purex [16]. Figures 1 and $2[27$ show schematically the various steps in each of these processes and also where samples are taken for plutonium measurements. Table I [2] shows a summary of the plutonium analytical programs for both recovery processes. Process sample analyses serve principally to provide plant inventory data for the plutonium, accurate knowledge of plant efficiencies, stream composition data important for efficiency control, and plutonium concentration data for nuclear safety reasons.

As indicated in Table I, alpha counting is the technique used in nearly all of the control analyses in plutonium production. It is routinely used for lean plutonium solutions such as waste streams, and also for highly radioactive solutions so that small aliquots may be analyzed. Direct alpha counting (without previous separation of the plutonium) is the simplest, and is used for such samples as the metal solution-blend streams $(R-1)$ and $(P-1)$, the codecontamination feed $(\mathrm{R}-2)$ and $(\mathrm{P}-2)$, and the feed to the plutonium recovery section $(\mathrm{R}-8)$ and $(\mathrm{P}-8)$. As in all radiochemical methods, the specific activity of the radionuclide being counted must be known. This is usually the case in plutonium production samples. If not, it must be calculated from isotopic distribution data obtained by mass spectrometer analyses. It is beyond the scope of this paper to discuss isotopic analysis. Corrections must also be made for all other alpha emitters, such as Am-241 and Cm-242, if present.

In solutions containing high salt or high fission product concentrations and low plutonium concentrations, a separation of the plutonium is necessary prior to alpha counting. Both lanthanum trifluoride carrying and thenoyltrifluoroacetone (TTA) extraction methods are employed. Waste streams and uranium stream samples, shown in Figures 1 and 2 by $(R-3),(P-3),(R-6)$ and $(P-6)$, are typical examples.

In the Redox process, streams in the plutonium-recovery cycle (low uranium) and also the product, are usually analyzed by an x-ray absorption method. Several other methods also are applicable to plutonium-rich solutions of this nature.

2. 1 Methods usually applied to dissolver and feed solutions

The determination of plutonium at this point, (Samples $(R-1)$ and $(P-1)$, Table I) establishes the amount produced in the reactor and is important, when. used in conjunction with samples $(R-1 U)$ and $(Y-\dot{y})$ ('lable $I)$, to establish the 
Table I. ROUTINE DEIERMINATIONS OF PLUTONIUM. IN THE REDOX AND PUREX PROCESSES

\begin{tabular}{|c|c|c|c|c|c|}
\hline \multirow[b]{2}{*}{ Sample } & \multicolumn{4}{|c|}{ Approximate composition } & \multirow[b]{2}{*}{ Usual method } \\
\hline & \multicolumn{2}{|l|}{ Redox } & \multicolumn{2}{|l|}{ Purex } & \\
\hline Metal-solution blend & $\begin{array}{l}2 \mathrm{~N} \mathrm{U}(\mathrm{VI}) \\
<\mathrm{C.} .3 \mathrm{~N} \mathrm{acid} \\
0.1 \mathrm{M} \mathrm{AI}\left(\mathrm{NO}_{3}\right)_{3} .\end{array}$ & $(R-1)$ & $\begin{array}{l}1.8 \mathrm{M} \mathrm{U}(\mathrm{VI}) \\
I \mathrm{~N} \text { acid. }\end{array}$ & $(P-1)$ & Direct alpha counting. \\
\hline Feed to codecontamination & $\begin{array}{l}\text { As above with } \\
\text { C. } 2 \mathrm{M} \operatorname{Cr}(V I) .\end{array}$ & $(\mathrm{R}-2)$ & As above & $(P-2)$ & Direct alpha counting. \\
\hline $\begin{array}{l}\text { Various column waste } \\
\text { streams throughout the } \\
\text { entire process }\end{array}$ & $\cdot$ & $(R-3)$ & & $(P-3)$ & Extraction, alpha counting. \\
\hline Feed to partitioning & $\begin{array}{l}1.3 \mathrm{M} \mathrm{U}(\mathrm{VI}) \\
1.1 \mathrm{M} \mathrm{Al}\left(\mathrm{NO}_{3}\right)_{3} . \\
0.2 \mathrm{~N} \text { acid-deficie } \\
0.06 \mathrm{M} \mathrm{Cr}(\mathrm{VI})\end{array}$ & (R-4). & $\begin{array}{l}1.8 \mathrm{M} \mathrm{U}(\mathrm{VI}) \\
1 \mathrm{~N} \text { acid. } \\
0.03 \mathrm{~N} . \\
\mathrm{NaNO}_{2}\end{array}$ & $(P-4)$ & Alpha counting. \\
\hline Feed to uranium recovery & $\begin{array}{l}\text { 2.6 M U(VI) } \\
0.2 \mathrm{~N} \text { acid-deficie }\end{array}$ & $\begin{array}{l}(\mathrm{R}-5) \\
\text { nt. }\end{array}$ & $\begin{array}{l}1.5 \mathrm{M} \mathrm{U}(\mathrm{VI}) \\
0.3 \mathrm{~N} \text { acid. } \\
0.014 \mathrm{M} \text { ferrous } \\
\text { sulfamate. }\end{array}$ & $(P-5)$ & Alphe counting. \\
\hline Uranium product & $\begin{array}{l}2.1 \mathrm{M} \mathrm{U}(\mathrm{VI}) \\
0.1 \mathrm{~N} \text { acid. }\end{array}$ & $(\mathrm{R}-6)$ & $\begin{array}{l}2.1 \mathrm{M} \mathrm{U}(\mathrm{VI}) \\
0.1 \mathrm{~N} \text { acid. }\end{array}$ & $(P-6)$ & TTA separation, alpha counting. \\
\hline Uranium trioxide product & $\mathrm{UO}_{3}$ & $(R-7)$ & $\mathrm{UO}_{3}$ & $(P-7)$ & TTA separation, alpha counting. \\
\hline Feed to plutonium recovery & $\begin{array}{l}1 \mathrm{M} \mathrm{Al}\left(\mathrm{NO}_{3}\right)_{3} \\
0.2 \mathrm{~N} \mathrm{acid.} \\
0.2 \mathrm{M} \mathrm{Cr}(\mathrm{VI})\end{array}$ & $(\mathrm{R}-8)$ & $\begin{array}{l}2.7 \mathrm{~N} \text { acid } \\
0.07 \mathrm{~N} \mathrm{Na}+ \\
0.01 \mathrm{M} \mathrm{Fe}\left(\mathrm{SO}_{4}\right)_{3}\end{array}$ & $(P-8)$ & Direct counting. \\
\hline $\begin{array}{l}\text { Feec to second-cycle plu- } \\
\text { tonium recovery }\end{array}$ & $\begin{array}{l}0.9 \mathrm{M} \mathrm{Al}\left(\mathrm{NO}_{3}\right)_{3} \\
0.2 \mathrm{~N} \text { acid. }\end{array}$ & $(\mathrm{R}-9)$ & Not applicable & & $\mathrm{X}$-ray absorptiometric. \\
\hline $\begin{array}{l}\text { Plutonium product } \\
\text { Plutonium-metal product } \\
\text { Concensates and cooling water }\end{array}$ & $6 \mathrm{~N}$ acid & $\begin{array}{l}(R-10) \\
(R-11)\end{array}$ & Same as Redox & $\begin{array}{l}(P-9) \\
(P-10)\end{array}$ & $\begin{array}{l}\text { X-ray absorptiometric. } \\
\text { Ceric titrimetric. } \\
\text { Direct counting. }\end{array}$ \\
\hline
\end{tabular}


overall recovery efficiency of the process. These solutions, intensely radioactive, mostly from their fission product contents, are analyzed for plutonium by direct alpha counting. Samples of dissolver solutions, $(R-1),(P-1),(R-2)$, and $(\mathrm{P}-2)$ (Table I), are taken in a shielded facility by remote pipetting, and diluted with nitric acid to a known volume. The size of the sample aliquot is dependent on the activity of the dissolver solution from a shielding standpoint and on the alpha activity from the instrument capability standpoint. The diluted solution is, at this point, removed from the shielded facility and the remainder of the analysis carried out without shielding. An accurate volume of the diluted and stirred solution, to provide 5,000 to 30,000 alpha disintegrations per minute, is pipetted onto a counting disk previously ringed with Zapon, evaporated by infrared heating, flamed to dull red, cooled, and counted.

Corrections for Am-241 and $\mathrm{Cm}-242$ are made on another aliquot by separating these two elements from plutonium by carrying them on cerium trifluoride, preparing a counting disk in the usual manner, and counting them together. For this separation the plutonium must first be oxidized with dichromate to the (VI) oxidation state which does not coprecipitate with cerium trifluoride.

Although it seems to be standard practice to use the direct alpha counting technique [1 $\overline{1}$ for measuring the plutonium in dissolver solutions, it is clear from Table I that these solutions are high in dissolved salts. Self absorption on the counting disk always exists, resulting in some negative bias. In order to correct this situation, previous extraction of the plutonium with TTA [3그 or a double extraction using hexone and TTA should be used [2 47 .

The techniques of alpha counting are too well known to require extended comment. Gas proportional counters, scintillation counters, and low geometry vacuum counters have been used satisfactorily. For some samples, tolerance of beta activity up to $10^{8}$ beta counts per minute is a requirement of the counting equipment.

\subsection{Methods usually applied to process solutions}

These include various column waste streams throughout the processes, such as $R-3$ and $P-3$ (Table $I$ ), and the purified uranium recovered, $(R-6)$ and $(P-G)$. These solutions contain relatively high concentrations of fission products and of uranium, and particularly low concentrations of plutonium. In these cases, it becomes necessary to extract the plutonium away from other coristituents prior to its measurement by alpha counting. 
The TTA extraction method $[\overline{3} \underline{1}]$ is very widely used. In this method, $100 \mu 1$ of dissolver solution is diluted to $10 \mathrm{ml}$ with $1 \mathrm{M}$ nitric acid, and $500 \mu 1$ of this solution is further diluted to $1.5 \mathrm{ml}$ with $2 \mathrm{M}$ nitric acid. The plutonium in this final aliquot is quantitatively reduced to the (III) oxidation state with hydroxylamine, then oxidized to the (IV) state with sodium nitrite. To this solution is then added a $0.5 \mathrm{M}$ solution of TTA in xylene which quantitatively extracts only the plutonium. A known volume of the TTA solution is pipetted on to the counting disk, evaporated to dryness, flamed to redness, and alpha counted in the usual manner. No corrections to the alpha count are necessary because other alpha emitters such as americium, curium, and neptunium (V) remain in the aqueous phase. When applied to a series of dis solver solutions, the relative standard deviation for a single determination was 3 to 5 percent. Analysis of a standard plutonium solution gave a recovery greater than 99.5 percent.

An improvement has been made in this method whereby the extraction is accomplished with a combination of hexone and TTA, resulting in better decontamination from fission products. As developed by Maeck, et alii. [2 4 I/, the plutonium is first separated from the remainder of the dissolver solution by a two-cycle extraction step. It is oxidized to the (VI) oxidation state with permanganate, extracted as the tetraalkylammonium trinitrate complex into methyl isobutyl ketone from an acid deficient salting solution. The plutonium is reduced to the (III) oxidation state with hydroxylamine and stripped from the organic phase into $3 \mathrm{M}$ nitric acid. It is then oxidized to the (IV) state with nitrite, and quantitatively extracted into TTA-xylene. Overall recovery of the plutonium was 98.8 percent with a relative standard deviation of 0.8 percent. The plutonium was determined by alpha counting. The need for uranium and americium-curium correstions is thereby eliminated, This is one advantage of the method.

Worthy of note is an $x$-ray absorptiometric method $[21]$ which is applied to the measurement of plutonium in the feed to the second-cycle plutonium recovery step in the Redox process. This solution has a relatively high concentration of plutonium and is also $0.9 \mathrm{M}$ in aluminum nitrate and $0.2 \mathrm{M}$ in nitric acid. The method applies best to a solution containing one atomic species of high atomic number. See Section 3.6.

2.3 Other methods applicable to dissolver or process solutions

On paper, at least, any of the methods listed in Section 3 can be used for determining plutonium in dissolver or process solutions, providing prior quantitative separation from the remaining constituents is accomplished. In a 
practical sense, however, this is not the case. Only those methods requiring small samples have possibilities of successful application because it is not practical to handle remotely, behind heavy shielding, those quantities of highly radioactive solutions required to yield, quantitatively, multimilligram amounts of plutonium.

Among those methods requiring small-size samples which have actually been applied to the determination of plutonium concentrations in dissolver solutions following prior separation of the plutonium are:

(a) Isotopic Dilution - Mass Spectrometer [327. To the sample of dissolver solution is added a known amount of Pu-242 (and U-233 if $U$ is analyzed for). The plutonium (and uranium) are oxidized to their (VI) oxidation states with permanganate in which form they are selectively extracted as the tetrapropylammonium complexes into methyl isobutyl ketone (hexone). The organic phase is separated, tetrahexylammonium iodide is added to it, and the reduced uranium and plutonium are stripped into hydrochloric acid. By the careful selection of the concentration of hydrochloric acid, the uranium to plutonium atom ratio in the extract can be chemically controlled. For example, if the ratio in the original solution is 250 to 1 , a final ratio of 12.6 to 1 is obtained when $4 \mathrm{M}$ hydrochloric acid is used. To the aqueous phase are then added a few drops of hydrogen peroxide and nitric acid and the solution is evaporated to fumes. The plutonium (and uranium) are determined by multiple filament mass spectrometry in which the singly charged metal ions are measured. From the knowledge of the volumes used, and the isotopic ratios of the spike, both the plutonium isotopic composition and the plutonium concentration of the dissolver solution can be calculated. One significant advantage of the method is that quantitative extraction of the plutonium from the dissolver solution is not required. Hence a possible source of bias is eliminated. Neither is a clean separation from the uranium required. As little as $10^{-}$gram of plutonium on the filament may be analyzed; practical considerations, however, suggest that approximately $10^{-7}$ gram actually be used. A uranium to plutonium ratio between 10 and 25 to one on the filament gives excellent results. The relative standard deviation of a single determination of plutonium concentration was reported to be 
about 0.7 percent for an isotopic population of $\mathrm{Pu}-239=92.69 \%$; $\mathrm{Pu}-240=6.74 \%$, and $\mathrm{Pu}-241=0.567 \%$.

(b) Controlled Potential Coulometric Titration $[1 \underline{3} \bar{T}$. The plutonium is separated by anion exchange from the remaining constituents of a Hanford-type dissolver solution. The plutonium is absorbed in the (IV) oxidation state from $8 \mathrm{M}$ nitric acid onto Dowex $1 \times 4$ resin. It is then eluted with $0.5 \mathrm{M}$ nitric acid - $0.02 \mathrm{M}$ hydroxylamine, and titrated. For the titration, the cell is equipped with a platinum mesh electrode. The sample is preoxidized, then reduced, the reduction step being used for the actual analysis. Standard dissolver solutions do not exist with which a comparison might be made. Analyses made on Hanford-type dissolver solutions by direct alpha counting and by coulometric titration showed that the relative standard deviation of the counting was about 2 percent as compared to 1.5 percent for the titration technique.

Coulometric techniques have not found wide acceptance.

(c) Potentiometric Titration, $\mathrm{Cr}$ (II) reduction-Ce(IV) oxidation [12]. See Section 3.2 (a). This method has been applied to the determination of $\mathrm{Pu}$, following its separation from Scrupp dis solver solutions. The $\mathrm{Pu}$ is extracted from the $2 \mathrm{M}$ nitric acid dissolver solution into 1 M TTA containing di-isopropyl ether, and then stripped into $10 \mathrm{M}$ hydrochloric acid. It is then reduced with $0.2 \mathrm{M}$ potassium iodide and passed through Dowex-1 to remove the U. Traces of iron are removed by a mercury cathode electrolysis. Titrations of plutonium samples as small as 100 $\mu \mathrm{g}$. were reported to be unbiased and showed relative standard deviations from 0.5 to $2 \%$.

(d) Spectrophotometric Methods. Several spectrophotometric methods have been developed, some of which are quite sensitive. (See Section 3.4). None of these has found application to the direct determination of plutonium in dissolver solutions of production reactor fuels for obvious reasons. However, any of the more sensitive of these methods may be used providing a clean cut separation of the plutonium from the uranium and fission products is first accomplished. A few applications of spectrophotometry to dissolver solutions from specific reactors have been reported $[22,2 \underline{5}]$. 
(e) X-Ray Fluorescence. This technique has not found acceptance for the routine analysis of dissolver solutions, nor of production process solutions. However, a method $[1]$ 으 has been developed whereby an analysis may be made on a sample containing a total amount of plutonium in the range of 0.4 to $0.8 \mathrm{mg}$. When applied to synthetic samples a relative standard deviation of less than 1 percent was reported. As in the case of all $x$-ray emission techniques, the matrix affects the results and must always be known and reproducible. Prior separation of the plutonium from the remaining constituents of any solution would be necessary to obtain a precision of less than 1 percent.

Limited applications of some methods have been made to the direct determination of plutonium in dissolver solutions (without prior separation of the plutonium). Included are the following methods:

(f) Controlled Potential Coulometric Titration $[4 \underline{0} /$. In early work by Scott and Peekema, a controlled potential coulometric technique similar, but not identical to that reported in Section 2.3 (b) was applied to the direct measurement of plutonium in dissolver solutions. The reproducibility of this method was 1 percent at the 95 percent confidence level.

(g) Scanning Coulometric Method. More recently, Propst $[\underline{3} \underline{8}]$ developed a highly sensitive method for determining plutonium in dissolver solutions which does not require a prior separation of the plutonium. The method makes use of an electroanalytical instrument called a scanning coulometer. It records coulombpotential curves of reversible processes under nearly equilibrium conditions. The circuit features a novel system for producing a scan rate that is an inverse function of the electrolysis current. Compensator networks provide automatic corrections for the continuous faradic current and the charging of the electrical double layer. It is reported that plutonium may be determined at the 2 to $5 \mu \mathrm{g}$ level with a relative standard deviation of 1 percent. The typical solution of irradiated nuclear fuel used was $1.4 \mathrm{M}$ in uranium and 0.5 to $1.0 \underline{\mathrm{M}}$ in $\mathrm{HNO}_{3} ; 25-\mu \mathrm{l}$ aliquots containing $3.3 \mu \mathrm{g}$ of $\mathrm{Pu}$ gave the above precision. Limited experience with this method indicates that it may be rather successful for this purpose. 
3. Determination of plutonium in metal, solutions, alloys, and compounds

\subsection{Preparation of samples}

Plutonium metal and most of its alloys are oxidized readily in air, especially in the presence of traces of moisture; therefore, pretreatment prior to analysis is required to remove surface contaminants. The preferred cleaning method for large regularly shaped pieces is mechanical polishing, either with a file or abrasive cloth, to expose a silvery metallic surface. This cleaning should be done at a slow rate, to prevent heating of the sample, and in an inert atmosphere, if possible. Small or irregularly shaped pieces of the metal and some alloys may be polished electrolytically in a 20 percent potassium carbonate electrolyte by making the sample the anode and using a tantalum cathode and a 22.5-volt dry-cell battery as a current source. The current flow is kept to the minimum that will expose a bright metallic surface, then the sample is washed immediately with water, ethanol, and methyl chloroform, in that order, and dried briefly in air or an inert atmosphere. Plutonium compounds generally do not require pretreatment, except for drying of stable materials prior to dissolution. Suitable solvents for some plutonium-containing materials are given in Tables II and III.

Removal of interfering ions often is required prior to analysis of plutonium-containing solutions. Addition of sulfuric acid, or nitric and perchloric acids, and repeated evaporations to strong fumes is recommended to eliminate volatile ions, such as nitrate or fluoride, and to destroy organic material. Undesired cations are removed by mercury cathode electrolysis from dilute sulfuric acid solutions, or by an anion exchange resin separation based upon selective adsorption of plutonium from 7.2 M nitric acid solution.

\subsection{Electrometric methods}

The electrometric techniques applied to the determination of plutonium include potentiometric, coulometric, and amperometric titrations, polarography, and chronopotentiometry. Potentiometric or amperometric titrations generally are used for the most precise determinations; applications of polarography and chronopotentiometry are very limited. Polarography has been used to measure the reduction-oxidation potentials of plutonium in solution $[\overline{8}, 1 \overline{4} /$, and more recently, preliminary work has shown that square wave polarography, using the plutonium(IV)-(III) couple in nitric or hydrochloric acids, is applicable to the determination of micromolar concentrations of plutonium $[2 \underline{0}$. The chronopotentiometric behavior of plutonium (III), (IV), and (VI) at a platinum electrode in various mineral acids was investigated to determine possible applications to analysis of plutonium $[\overline{3} \underline{\overline{5}}]$. Well-defined chronopotentiograms 


\section{Type Sample}

Alloys with:

$$
\begin{aligned}
& \mathrm{Al}, \mathrm{Bi}, \mathrm{Cd}, \mathrm{Ce}, \mathrm{Cr}, \mathrm{Co}, \mathrm{Fe}, \mathrm{Ga}, \\
& \text { In, La, Mg, Mn, Mo, Ni, Si, Sn, } \\
& \text { Ti, Th, U, V, or } \mathrm{Zn} \text {. }
\end{aligned}
$$

$\mathrm{Cu}, \mathrm{Hg}, \mathrm{Rh}$

$\mathrm{Ru}$, or Ru, Mo, Zr, Ce, La, Na, and $\mathrm{Fe}$

Platinum metals

$\mathrm{Nb}, \mathrm{Si}, \mathrm{Ta}$

$\mathrm{Nb}, \mathrm{Ta}, \mathrm{Zr}$

Al or Al and SI

Ce-Co, Ce-Co-Mn, or Ce-Ni

High purity metal and metal

containing such impurities as:

$$
\begin{aligned}
& \mathrm{Al}, \mathrm{B}, \mathrm{Ca}, \mathrm{Cd}, \mathrm{Cs}, \mathrm{Ce}, \mathrm{Cr}, \mathrm{Co}, \\
& \text { Fe, La, Li, Mg, Mn, Mo, Ni, } \\
& \text { F, Sr, } \mathrm{Na}, \mathrm{Si}, \mathrm{Sn}, \mathrm{Ti}, \mathrm{Th}, \mathrm{U}, \\
& \text { V, Zn, } \mathrm{Zr}
\end{aligned}
$$

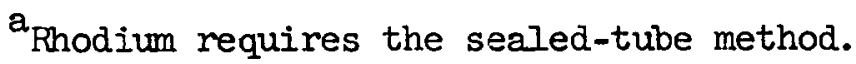

$\mathrm{b}_{\mathrm{RuO}_{4}}$ distilled.

\section{Suitable Solvents}

3 to $12 \mathrm{M} \mathrm{HCl}$ or $\mathrm{HClO}_{4}$

$$
\begin{aligned}
& \mathrm{HCl}-\mathrm{HNO}_{3}\left(300^{\circ} \mathrm{C}\right)^{\mathrm{a}} \\
& \mathrm{HCl}-\mathrm{HClO}_{4} \text { (boiling) }{ }^{\mathrm{b}} \text { or } \\
& \mathrm{HF}-\mathrm{HNO}_{3}-\mathrm{H}_{2} \mathrm{SO}_{4} \text { and } \mathrm{NaNO}_{3}- \\
& \mathrm{NaOH} \text { fusion } \\
& \mathrm{HCl}-\mathrm{HClO}_{4}\left(300^{\circ} \mathrm{C}\right)^{\mathrm{d}}
\end{aligned}
$$

$\mathrm{Hg}$ catalyzed $\mathrm{HNO}_{3}$

$12 \mathrm{M} \mathrm{HCl}$

3 to $12 \mathrm{M} \mathrm{HCl}$, other halogen

${ }^{c}$ Alternate acid and fusion treatments.

'Wichers' sealed-tube method [45]. 
Table III. SOLVENTS FOR PLUTONIUM COMPOUNDS

\section{Type Sample}

Compounds:

$\mathrm{PuF}_{3}, \mathrm{PuF}_{4}$

$\mathrm{Pu}\left(\mathrm{IO}_{5}\right)_{3}, \mathrm{Pu}\left(\mathrm{IO}_{3}\right)_{4}, \mathrm{Pu}_{2}\left(\mathrm{C}_{2} \mathrm{O}_{4}\right)_{3}$,

$\mathrm{Pu}\left(\mathrm{C}_{2} \mathrm{O}_{4}\right)_{2}, \mathrm{PuO}_{4}{ }^{\circ} \times \mathrm{H}_{2} \mathrm{O}$,

$\mathrm{BiPuH}\left(\mathrm{C}_{2} \mathrm{C}_{4}\right)_{4}, \mathrm{PuBiO}_{3}$,

$\mathrm{NaPuO}_{2}\left(\mathrm{C}_{2} \mathrm{H}_{3} \mathrm{O}_{2}\right)_{3}$

$\mathrm{PuCl}_{3}, \mathrm{PuCl}_{4}, \mathrm{Pu}\left(\mathrm{NO}_{3}\right)_{4}, \mathrm{Pu}\left(\mathrm{SO}_{4}\right)_{2}$, $\mathrm{Pu}\left(\mathrm{ClO}_{4}\right)_{4}, \mathrm{PuO}_{2} \mathrm{Cl}_{2}, \mathrm{FuOl}_{2}\left(\mathrm{NOO}_{3}\right)_{2}$, $\mathrm{PuO}_{2}\left(\mathrm{ClO}_{4}\right)_{2}$

$\mathrm{PuO}_{2}$

Double chloride, nitrate, or perchlorate salts with $\mathrm{Ca}, \mathrm{Cs}, \mathrm{Ce}, \mathrm{La}, \mathrm{Li}, \mathrm{Mg}, \mathrm{K}$, $\mathrm{Sr}$, or $\mathrm{Na}$

Pu peroxides

Pu carbides

$\mathrm{Pu}$ nitrides
Suitable Solvents

Hot concnd. $\mathrm{HNO}_{3}, \mathrm{HClO}_{4}$, or $\mathrm{H}_{2} \mathrm{SO}_{4}$; $\mathrm{Al}\left(\mathrm{NO}_{3}\right)_{3}$ and $\mathrm{HNO}_{3}$

Hot conend. $\mathrm{HNO}_{3}, \mathrm{HClO}_{4}$, or $\mathrm{H}_{2} \mathrm{SO}_{4}$

Water, followed by dilute acid to prevent hydrolysis

$\mathrm{HF}-\mathrm{HNO}_{3}-\mathrm{H}_{2} \mathrm{SO}_{4} ; \mathrm{NH}_{4} \mathrm{HF}_{2}$ fusion, then hot $\mathrm{HNO}_{3} ; \mathrm{Na}_{2} \mathrm{O}_{2}$ fusion, then hot $\mathrm{HNO}_{3} ; \mathrm{HCl}_{-\mathrm{HClO}_{4}}\left(300^{\circ} \mathrm{C}\right)^{\mathrm{a}}, \mathrm{HBr}$ (reflux)

3 to $12 \mathrm{M} \mathrm{HCl} ; 1$ to $6 \mathrm{M} \mathrm{HNO}_{3}$

$\mathrm{HCl}$ or $\mathrm{HNO}_{3}$ with $\mathrm{Mn}(\mathrm{II}), \mathrm{Ce}(\mathrm{IV}), \mathrm{Sn}(\mathrm{II})$, or $I(I)$

$\mathrm{HCl}, \mathrm{HNO}_{3}, \mathrm{HClO}_{4}$, or $\mathrm{H}_{2} \mathrm{SO}_{4} ; 15 \mathrm{M} \mathrm{HNO}_{3}-$ $6 \mathrm{M} \mathrm{HF} \mathrm{(reflux)} \mathrm{if} \mathrm{difficultly}$

soluble

Dilute $\mathrm{HCl}, \mathrm{HNO}_{3}, \mathrm{HClO}_{4}$, or $\mathrm{H}_{2} \mathrm{SO}_{4}$

'Wichers' sealed-tube metiod [45]. 
were obtained for electro-oxidation of plutonium(III) in perchloric acid, but analytical methods based upon this technique have not been developed.

(a) Potentiometric methods

The potentiometric titration methods are based upon either the oxidation of plutonium(III) or the reduction of plutonium(VI) to the (IV) oxidation state which is stabilized by complexing with sulfate ion. Generally, elimination of interfering anions, such as fluoride and nitrate, by a preliminary fuming operation is prerequisite to successful titration. Determinations involving the plutonium(VI)-(IV) couple have the potential advantage of greater sensitivity, because of the two electron change, but concern for high reliability predominates in selection of sample size, usually 5 to $200 \mathrm{mg}$. of plutonium. For the same reason, weight burets or accurate screw-driven syringe burets generally are used for taking aliquots and for adding titrants.

In one of the first reliable titration methods $[\overline{2} \underline{\underline{9}} /$, an excess of titanium(III) is added to reduce the plutonium quantitatively to the (III) oxidation state. Addition of cerium(IV) solution produces sharp end points for the oxidation, first of the excess titanium(III), and second, of the plutonium(III). In titrating 4 to $6 \mathrm{mg}$. of plutonium, a relative standard deviation of 0.15 percent is possible routinely. Iron, chromium, vanadium, platinum, and gold cause interference.

Chromium(II) is used as the reductant in a micro titration method $[3 \underline{\underline{4}} \overline{7}$ for determining 0.1 to $0.2 \mathrm{mg}$. of plutonium. An aliquot of the sample solution is fumed with sulfuric acid, and a slight excess of chromium(II) is added. The excess chromium(II) and then the plutonium(III) are titrated with cerium(IV). The two endpoints are detected by using a bimetallic gold-platinum electrode system, and the titration curve is plotted by a recorder. The relative standard deviation of a single determination is 0.5 percent. Iron, uranium, vanadium, platinum, and gold interfere. For application of this method to the determination of 0.2 to $0.4 \mathrm{mg}$. per $\mathrm{ml}$. of plutonium, following separation from irradiated uranium fuel slugs, see Section 2.2. 
Titration methods in which the plutonium is reduced with zinc amalgam have the advantage of requiring detection of only one endpoint. In a very reliable method $[\overline{1}, 2 \underline{9} /$, the sulfuric acid solution of the sample is stirred for 30 to 60 minutes in contact with liquid zinc amalgam in a special microtitration cup. The amalgam is withdrawn through a capillary sealed to the bottom of the cup, and the plutonium(III) is titrated with cerium(IV) using a platinum-calomel electrode system to detect the endpoint. For a single determination of $25 \mathrm{mg}$. of plutonium, the relative standard deviation is 0.06 percent. Iron, chromium, vanadium, molybdenum, titanium, gold, and platinum interfere.

In another method $[3 \bar{l} /$, amalgamated zinc in the form of a Jones reductor is used as a reductant for plutonium in $4 \mathrm{~N}$ sulfuric acid solution. The plutonium(III) is titrated with standard potassium dichromate solution, using polarized gold electrodes to indicate the endpoint. A relative standard deviation of 0.04 percent was reported for a single determination of 70 to $140 \mathrm{mg}$. of plutonium. Metals, except chromium, that interfere in the above method also cause interference here. This method was applied to the determination of plutonium (following its separation) in plutonium oxide-uranium oxide, and in plutonium-uranium carbide fuel elements. Separation was accomplished by a cation exchange resin method in which plutonium and uranium were adsorbed on Dowex-50 resin from $0.3 \mathrm{M}$ nitric acid-0.05 $\underline{\mathrm{M}}$ hydroxylamine solution. The uranium was eluted with $0.3 \mathrm{M}$ sulfuric acid-0.05 $\mathrm{M}$ hydroxylamine, then plutonium was eluted with 6 M nitric-0.05 M sulfamic acid. Reported recovery of plutonium was greater than 99 percent and the relative standard deviations of the determinations were in the range of 0.1 to 1.0 percent $[3 \underline{6}]$.

In the most precise potentiometric method [4 $4 \overline{4}$, at least $180 \mathrm{mg}$. of plutonium are oxidized with fuming perchloric acid to plutonium (VI) which is reduced to plutonium(III) and (IV) by adding a slight excess of iron(II) solution. Titration of the plutonium(III) and excess iron(II) with cerium(IV), using a platinum-calomel electrode system, completes the determination which has a relative standard deviation of 0.02 percent. Chromium, gold, manganese, and vanadium interfere. 
A variation of this method was proposed recently $\overline{2} \underline{2} \overline{1} /$ in which argentic "peroxide" in $1 \mathrm{M}$ sulfuric acid oxidizes the plutonium to the (VI) state, and $0.50 \mathrm{~N}$ potassium dichromate solution is the oxidant used in the back-titration of excess iron(II). With this system a smaller break in potential is obtained at the endpoint. Preliminary tests indicate a relative standard deviation of 0.3 percent. The effect of various ions on the determination was not reported.

(b) Amperometric methods

Plutonium may be determined quite precisely by titration of plutonium (VI) with iron(II) in which the endpoint is detected amperometrically with a rotating platinum electrode $[4 \underline{1}]$. The plutonium is oxidized to the (VI) oxidation state with argentic oxide, the excess oxidant is destroyed by heating, and then the plutonium(VI) is titrated to the (IV) oxidation state by the addition of standard iron(II) sulfate. Relative standard deviations are 0.05 percent for sample sizes of 10 to $20 \mathrm{mg}$. and 0.4 percent for $0.2 \mathrm{mg}$. of plutonium. For the smaller quantity, there is a negative bias of 0.6 . percent, but there is no significant bias if the sample size is greater than $10 \mathrm{mg}$. Metals that interfere with this method include cerium, chromium, manganese, and vanadium.

(c) Coulometric methods

Constant current and controlled potential coulometry have been shown to apply to the determination of plutonium in dissolver solutions, process solutions, and product plutonium. Constant current methods were developed first, but the advent of simple and reliable instruments for controlled potential coulometry led to greater use of this latter technique. The constant current coulometric titrations involve redox reactions of the plutonium (III)-(IV) and (VI)-(IV) couples. In methods involving the plutonium(III)-(IV) couple, plutonium is reduced electrolytically in nitric acid-sulfamic acid solution or by adding a slight excess of chromium(II) or titanium(III) ions $[5-\underline{7}]$. Then the plutonium(III) is titrated coulometrically with electrolytically generated bromine or cerium(IV), using a potentiometric detection of the endpoint. 
Wide acceptance did not follow introduction of these methods because of experimental difficulties that include large reagent blanks caused by impurities, and oxidation of plutonium(III) by anodic products diffusing into the main titration compartment of the titration cell. Some of these methods are tentative and are based upon limited investigations that have not been continued. A method $[\bar{I}]$ involving the plutonium(VI)-(IV) couple seems to be more reliable and is not influenced by iron impurities. This method, which applies to the determination of 0.003 to $10 \mathrm{mg}$. of plutonium, starts with the oxidation of the plutonium to the (VI) oxidation state with permanganate and bismuthate. The manganese dioxide that is formed is destroyed with formaldehyde or sodium azide, and the plutonium(VI) is titrated to plutonium(IV) with electrolytically generated iron(II) sulfate. The endpoint is determined potentiometrically. Relative standard deviations are 5 percent and 1 percent in determining $0.003 \mathrm{mg}$. and $1 \mathrm{mg}$. of plutonium, respectively. Separation of the plutonium by a lanthanum fluoride carrier coprecipitation eliminates interference from most elements except cerium and oxygen.

Controlled potential coulometric determinations $[\overline{3} 9,40,42,4 \underline{\overline{3}}]$ utilize titration cells that have either a mercury working electrode, with a citrate-buffered aluminum sulfate electrolyte, or a platinum working electrode with 1 M hydrochloric, nitric, or perchloric acid as the electrolyte. Recently, phosphate electrolytes were reported to be satisfactory $[2 \underline{6}]$. The coulometric oxidation of plutonium(III) to (IV) is the preferred reaction in the mercury cell, but either the coulometric oxidation of plutonium(III) or reduction of plutonium(IV) is a satis factory electrode reaction in the platinum cell. Relative standard deviations of these determinations increase from 0.1 percent for samples greater than $2 \mathrm{mg}$. to 1 percent for 0.05 mg. Anions that must be removed by fuming prior to the titration include nitrite, thiocyanate, peroxide, and fluoride. Judicious choice of potential and electrolyte prevents interference by most metal ions. 
The simplicity of controlled potential coulometry in determining plutonium in complex solutions is evident in a typical application $[4 \underline{2} /$ to a plutonium "product" solution. An aliquot containing 5 $\mathrm{mg}$. of plutonium is warmed with nitric acid, then the plutonium is reduced coulometrically in a perchloric-sulfamic acid electrolyte. Following this pretreatment, the integrated current to oxidize the plutonium to the (IV) oxidation state is measured and related to plutonium concentration. Small amounts of iron and uranium do not interfere. As mentioned previously, controlled potential coulometry may be applied to reactor fuel dissolver solutions, either directly or following anion exchange resin separation of the plutonium. However, this technique has not been adopted as a routine method.

\section{3 Volumetric methods}

One of the earliest methods $[\overline{1} \underline{8} \overline{7}$ for determining plutonium consisted of reduction of plutonium to the (III) oxidation state in a Jones reductor and subsequent titration to plutonium(IV) with standardized cerium(IV) solution. Ferrous o-phenthroline was used as a color indicator in the visual detection of the endpoint. This method was modified recently to include photometric detection of the color change of the indicator $[4 \bar{J}$; this change improved the precision of the method to a relative standard deviation of 0.03 percent when employing a 0.5 -gram sample.

\section{4 Spectrophotometric methods}

Applications of spectrophotometric methods have been limited because of difficulties caused by multiplicity of plutonium oxidation states, each of which has a characteristic spertrum and reacts differently with color-forming reagents, and by the low molar absorptivities of the plutonium ions. However, spectrophotometry has the advantage, compared to radiochemical methods, of not requiring a knowledge of the isotopic population of the plutonium.

These methods are based upon measurement of the absorbance of the plutonium ions directly, or of colored complexes formed with some reagent. Color-forming reagents generally are used in methods for determining microgram quantities of plutonium. Sodium alizarin sulfonate forms with plutonium (IV) a complex that has a molar absorptivity of 9870 when measured at $530 \mathrm{~m} \mu$; this method applies to the determination of 2 to 15 micrograms of plutonium per milliliter with relative standard deviations not greater than 2 percent [1] This reagent is not selective or particularly sensitive, and the method has not found wide acceptance. 
More recently, a method was developed in which the absorbance of the plutonium(IV)-arsenazo I complex, formed in $0.4 \mathrm{M}$ perchloric acid solution, is measured at a wavelength of $600 \mathrm{~m} \mu[\mathrm{g}]$. The large molar absorptivity of this complex, 22,000, makes the method very sensitive; 20 to $100 \mu \mathrm{g}$. of plutonium in a $10-\mathrm{ml}$. volume are determined with relative standard deviations no greater than 2 percent, and $5 \mu \mathrm{g}$. is determined with a relative standard deviation of 6 percent. At the $0.4 \mathrm{M}$ acidity, the interference caused by uranium at lower acidities is virtually eliminated, but several other metals cause interference. Separation of the plutonium by anion exchange resin or fluoride precipitation are incorporated into the method to reduce the number of interfering ions.

Larger concentrations of plutonium (from 145 to $170 \mathrm{mg}$. per gram of solution) may be determined directly by reducing the plutonium with ascorbic acid and measuring the absorbance of the plutonium(III) at $562 \mathrm{~m} \mu$. A highdensity reference prepared from the perchlorate salts of chromium(III), cobalt(II), and copper(II) is the reference solution. Careful control of temperature and other variables, and use of weight burets, make this method precise; a relative standard deviation of 0.11 percent was reported $[3]$. Application has been made to nitrate recovery solutions and to plutonium metal dissolved in hydrochloric acid.

\section{5 Radiochemical methods}

Radiochemical methods may be employed if high precision is not required. They are applied to an extremely wide range of plutonium concentrations, and with adequate separation of the plutonium from other constituents, application is made to a very great variety of solutions. The most useful application is to dilute solutions and arises because quantities as small as $10^{-10}$ gram can be measured reliably, a capability frequently exploited in biological work.

The simplest condition in which plutonium is encountered is in a solution of one of its salts without other dissolved salts being present. In such cases, following proper dilution, if necessary, a suitable aliquot is transferred to a counting plate, dried under controlled conditions, flamed to a dull red heat, and alpha counted. In case the sample contains other dis solved but nonradioactive salts, the direct evaporation technique may still be used, providing the ratio of dissolved salts to plutonium is not too great. The quantity of salls on the counting plate should not exceed 100 to $200 \mu \mathrm{g}$. 
If the dissolved salt content is too great and interferes too seriously for the precision required, the plutonium frequently is separated by coprecipitation with lanthanum fluoride. The lanthanum ion is added in specific amounts in the form of lanthanum nitrate, and fluoride ion is added in the form of hydrofluoric acid or ammonium fluoride. Plutonium(III) and (IV) are carried quantitatively by the lanthanum trifluoride precipitate. The solution is centrifuged, and the precipitate is slurried with nitric acid and transferred to a counting plate for drying and counting in the usual manner. Correction is made for the selfabsorption caused by the carrier. Other precipitating or carrying agents include bismuth phosphate, lanthanum hydroxide, zirconium phosphate, and thorium pyrophosphate; the oxalates of thorium, uranium(IV), bismuth, and lanthanum; and the iodates of cerium, thorium, and zirconium.

In general, ion exchange or liquid-liquid extraction techniques are preferred for separating plutonium from irradiated reactor fuel solutions. Anion exchange resin systems employ either nitric acid or hydrochloric acid solutions for the loading solutions, and elution of the plutonium is accomplished with dilute acid, or complexing or reducing agents such as fluoride or hydroxylamine. Several cation exchange resin systems also have been reported for this purpose. However, liquid-liquid extraction techniques are less timeconsuming than ion exchange techniques, and in addition, the latter frequently separate the element into a volume of solution too large to handle conveniently. For these reasons liquid-liquid extraction methods are preferred to anion exchange techniques.

One excellent extraction method for determining plutonium employs 0.5 M TTA in xylene as the extractant $[\overline{3} \underline{1} /$. Plutonium(IV) is extracted from $1 \underline{M}$ nitric acid and then stripped from the organic phase into $10 \underline{M}$ nitric acid. A second extraction with TTA removes traces of gamma activity. Other useful extractants include tri-isooctyl amine in xylene, cupferron, and mixtures of TBP and TTA. Following the selected separation method, an aliquot of the plutonium solution is evaporated, or the plutonium is electrodeposited as a compound, on a counting disk, and the appropriate radioactivity measurements are made. Radiochemical methods generally are not highly precise, but they are selective, rapid, and very sensitive.

3.6 X-Ray methods

(a) Absorption

For assaying plutonium in high purity samples, an $x$-ray absorption method has been developed [217. Using a "criss-cross" technique in a split beam $\mathrm{x}$-ray photometer, with optimum 
conditions of a $12-\mathrm{cm}$. cell path and a plutonium concentration of 36 grams per liter in a solution of known acidity, a relative standard deviation of 0.3 percent was achieved. This method works best for clean solutions. For impure solutions, the plutonium is separated by solvent extraction with TBP. Then the organic phase is analyzed for plutonium by $\mathrm{x}$-ray absorption using a fluorescent-screen type, $x$-ray photometer. This method has a relative standard deviation of 0.5 percent in determining 5 to $70 \mathrm{mg}$. of plutonium per milliliter of solution $[197$. However, it should be pointed out that this absorption method measures total absorption of all solutes, solvents, and cell. The method has not gained wide acceptance. This is probably due, at least in part, to the non-availability of a commercial instrument.

Recently, a newer technique [1 $5 \overline{7}, x$-ray absorption edge analysis, has been applied to improve the selectivity for the determination of plutonium. In this method secondary $x$-rays, generated by irradiating a niobium-molybdenum metal target with $x$-rays from a tungsten target $x$-ray tube, are transmitted through the sample solution and through standard solutions. The relative absorptions by the sample solution, and by the standard solutions, of these two $x$-rays, one located closely on each side of an absorption edge of plutonium, are used to calculate the plutonium concentration. For determining plutonium concentrations in alloys which vary from 30 to 100 percent, the relative standard deviations vary from 0.91 to 0.55 percent. Only radon, radium, neptunium, and americium have absorption edges between the $\mathrm{x}$-rays used in this method.

(b) Fluorescence methods

In addition to the example cited in Section 2 (e), another $x$-ray emission method which has been recommended for determining plutonium in refractory oxides [2ㄱ․ The sample, to which thorium has been added as an internal standardo and to reduce matrix effects, is fused with potassium pyrosulfate, cooled to form pellets, and the $x$-rays of thorium and plutonium are measured. The relative standard deviation in determining 1 to $10 \mathrm{mg}$. of plutonium is reported to be 3.2 percent, but this can be reduced to 0.6 percent by polishing the pellets prior to analysis. 
A complete analysis of super-pure plutonium metal consists of determining all known impurities, using the most sensitive methods available, and of assaying for the plutonium content using the most reliable of the assay methods. Recent developments in purifying plutonium by electrorefining from molten salt baths have led to almost routine production of very pure metal $[3 \underline{3}]$. Various analytical techniques are required for the analysis of the super-pure metal made by this process. Approximately thirty impurities are determined by spectrochemical methods. These methods utilize two general techniques: (a) carrier distillation to effect partial separation of the impurities from the plutonium by selective volatilization of the impurities and suppression of the plutonium spectrum; in this technique a blend of the ignited sample with gallium oxide, silver chloride, or sodium fluoride is excited in a cratered electrode; and (b) separation of the plutonium from the impurities by ion exchange resin, fluoride precipitation, or extraction methods, and evaporation of an aliquot of the impurity solution onto the electrode for arcing $[\overline{3} \underline{0}]$.

Spectrophotometric, physicochemical, or radiochemical methods are applied to determination of those elements for which emission spectrography is not applicable or too insensitive $[\underline{3} \underline{0} /$. Spectrophotometric methods often are used to determine $\mathrm{Ce}, \mathrm{Fe}$, Hf, Mo, N, No, P, Ta, Th, U, W, and Zr. Methods exist also for the following elements: $\mathrm{B}, \mathrm{Cd}, \mathrm{Co}, \mathrm{Cr}, \mathrm{Ga}, \mathrm{Mn}, \mathrm{Ni}, \mathrm{Pt}, \mathrm{Rh}, \mathrm{Ru}$, $\mathrm{S}$, Si, Ta, and $\mathrm{Zn}$. Physicochemical methods are applied to the determinations of oxygen, carbon, fluoride, and chloride. Radiochemical methods are used in determining americium and neptunium.

The assay of super-pure plutonium requires extreme care to obtain a reliability that makes the results meaningful. The best methods have relative standard deviations of 0.02 to 0.03 percent. This variance is greater than the total of the impurity concentrations, and a large number of determinations are required to obtain an average assay value of sufficient reliability. Of the methods described previously, those which have been applied to the assay of super-pure plutonium are: amperometric titration of plutonium(VI) with iron(II), potentiometric titration in which plutonium is reduced to the (III) oxidation state with zinc amalgam and then titrated with cerium(IV), and potentiometric titration of plutonium(VI) with iron(II). All of the high-precision methods described in this paper are suitable. Although detailed descriptions of methods for the analysis of super-pure metal perhaps are not necessary for analysts familiar with this field, it is worthy of note that present methods for the determination of trace amounts of impurities in super-pure metal permit the 
meaningful analysis of metal having a total impurity content of the order of $100 \mathrm{ppm}$. Methods for the parts-per-billion range of impurities remain to be developed.

Sponsored by the United States Atomic Energy Commission. 


\section{REFERENCES}

1. BOAZ, H. E., United States Atomic Energy Comission Report LA(Los Alamos Scientific Laboratory) - 507 (1946).

2. BOOMAN, G. I., and REIN, J. E., in Analysis of Essential Nuclear Reactor Materials (Rodden, C. J., ed.) Division of Technical Information, United States Atomic Energy Comission, Washington, D. C. (1964) 502-508.

3. BYRNE, J. T., Private Communication, Rocky Flats Division, Dow Chemical Company, Denver, Colorado.(1961).

4. BYRNE, J. T., et alii., in Selected Measurement Methods for Plutonium and Uranium in the Nuclear Fuel Cycle (Jones; R. J., ed.) Division of Technical Information, United States Atomic Energy Commission, Washington, D. C. (1963) 309-315.

5. CARSON, W. N., JR., United States Atomic Energy Commission Report HW(Hanford Works) - 18161 (1950).

6. CARSON, W. N., JR., United States Atomic Energy Commission Report HW(Hanford Works) -24729 (1952).

7. CARSON, W. N., JR., et alii., Analytical Chemistry 29 (1957) 1417.

8. COOK, G. P., et ali1., Analytica Chimica Acta 19 (1958) 174.

9. DAHLBY, J. W., and WATERBURY, G. R., United States Atomic Energy Commission Report ILA(Los Alamos Scientific Laboratory)-3314. (1965).

10. FLIKKEMA, D. S., and SCHABLASKE, R. V., United States Atomic Energy Commission Report ANL(Argonne National Laboratory)-5804 (1957).

11. FOSTER, R. W., in Selected Measurement Methods for Ylutonium and Uranium in the Nuclear Fuel Cycle (Jones, R. J., ed.) Division of Technical Information, United States Atomic Energy Commission, Washington, D. C. (1963) $361-366$.

12. FOSTER, R. W., and COOPER, J. H., United States Atomic Energy Commission Report ORNL (Oak Ridge National Laboratory)-1854 (1955).

13. HANDSHUH, J. W., United States Atomic Energy Comission Report HW(Hanford Works) - 66441 (1960).

14. HARVEY, B. G., et alii., Journal of the Chemistry Society (British) (195\%) 1010. 
15. HURTEY, R. G., et ali1., United States Atomic Energy Comission Report. LA(Los Alamos Scientific Laboratory)-3258 (1965).

16. IRISH, E. R., and REAS, W. H., in Symposium on the Reprocessing of Irradiated Fuels, Brussels, Belgium, May 20-25, 1957, United States Atomic Energy Comnission Report TID(Technical Information Division)-7534, Book 1 (1957) 83-129.

17. KING, G. I., United States Atomic Energy Comission Report IA(Los Alamos Scientific Laboratory)-1197 (1951).

18. KOCH, C. W., in The Transuranium Elements 14B (Seaborg, G. T., Katz, J. J., and Manning, W. M., eds.) National Nuclear Energy Series, Division IV, McGraw-Hill Book Co., Inc., New York (1949) $1337-1338$.

19. KOFOED, R. J., in Selected Measurement Methods for Plutonium and Uranium in the Nuclear Fuel Cycle (Jones, R. J., ed.) Division of Technical Information, United States Atomic Energy Commission, Washington, D. C. (1963) $351-355$.

20. KOYAMÁ, K., Analytical Chemistry 32 (1960) 523.

21. LAMBERT, M. C., United States Atomic Energy Comission Report HW(Hanford Works) -26499 (1952).

22. LARSEN, R. P., and SEIIS, C. A., JR., Analytical Chemistry 32 (1960) 1863.

23. LAWROSKI, S., and LEVEIVSON, M., in Symposium on the Reprocessing of Irradiated Fuels, Brussels, Belgium, May 20-25, 1957, United States Atomic Energy Comission Report TID(Technical Information Division)7534, Book 1 ( 1957) 45-82.

24. MAECK, W. J., et alii., Analytical Chemistry 32 (1960) 605-607.

25. MAECK, W. J., et alii., Analytical Chemistry 33 (1961) 998.

26. MENIS; 0., et alii., United States Atomic Energy Comission Report NUMEC(Nuclear Materials and Equipment Corporation)-2389-4 (1963) 14-24.

27. MENIs, 0., et alii., Analytical Chemistry 35 (1963) 1049.

28. MENIS, 0., et alii., United States Atomic Energy Comission Report NUMEC(Nuclear Materlals and Equipment Corporation)-90 (1962).

29. METZ, C. F., Analytical Chemistry 29 (1957) 1748. 
30. METZ, C. F., and WATERBURY, G. R., in Treatise on Analytical Chemistry Part II, 9 (Kolthoff, I. M., and Elving, P. J., eds.) Interscience Publishers, New York-London (1962) 329-332.

31. MOORE, F. I., and HUDGENS; J. E., JR., Analytical Chemistry 29 (1957) 1767.

32. MORGAN, T. D., and REIN, J. E., in Selected Measurement Methods for Plutonium and Uranium in the Nuclear Fuel Cycle (Jones, R. J., ed.) Division of Technical Information, United States Atomic Energy Commission, Washington, D. C. (1963) 291-305.

33. MULINS, L. J., et alii., United States Atomic Energy Comission Report. LA(Los Alamos Scientific Laboratory)-2666 (1962).

34. Oak Ridge National Laboratory, Master Analytical Manual, United States Atomic Energy Commission Report TID(Technical Information Division)-7015 (1953) Method 9,0432620-1.

35. PETERS, D. G., and SHULTS, W. D., Journal of Electroanalytical Chemistry $8(1964) 200$.

36. PIETRI, C. E., United States Atomic Energy Commission Report NBL(New Brunswick Laboratory) -189 (1963).

37. PIETRI, C. E., and BAGLIO, J. A., Talanta 6 (1960) 159.

38. PROPST, R. C., Analytical Chemistry 35 (1963) 958.

39. SCOTT, F. A., and PEEKEMA, R. M., in Proceedings of the Second United Nations Intermational Conference on the Peaceful Uses of Atomic Energy 28, United Nations Publications, Geneva (1958) 573-578.

40. SCOTT, F. A., and PEEKETMA, R. M., United States Atomic Energy Commission Report HW(Hanford Works) -58491 (1958).

41. SEILS, C. A., JR., et alii., Analytical Chemistry 35 (1963) 1673-1675.

42. SHULTS, W. D., United States Atomic Energy Commission Report ORNL(Oak Ridge National Laboratory)-2921 (1960). .

43. SHULIS, W. D., et alii., United States Atomic Energy Comission Report ORNL(Oak Ridge National Laboratory)-2776 (1959).

44. WATERBURY, G. R., and METZ, C. F., Analytical Chemistry 31 (1959) 1144.

45. WICHERS, E., et alii., Journal of Research of the National Bureau of Standards 33 (1944) 363, 457 . 


\section{Captions for Figures}

Fig. 1. Flow sheet for Redox recovery process $[27$.

Fig. 2. Flow sheet for Purex recovery process $[2]$. 


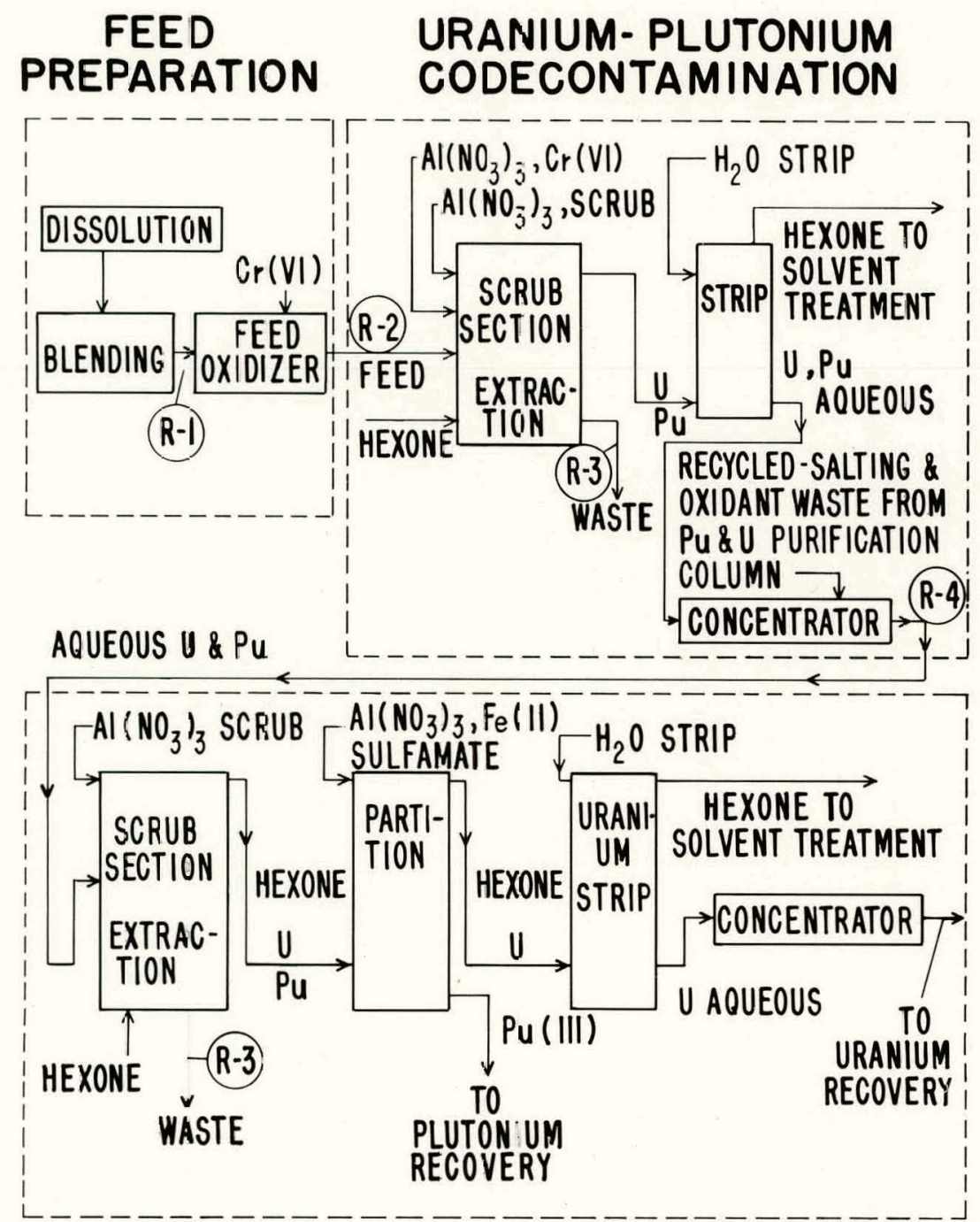

URANIUM-PLUTONIUM PARTITIONING
URANIUM RECOVERY

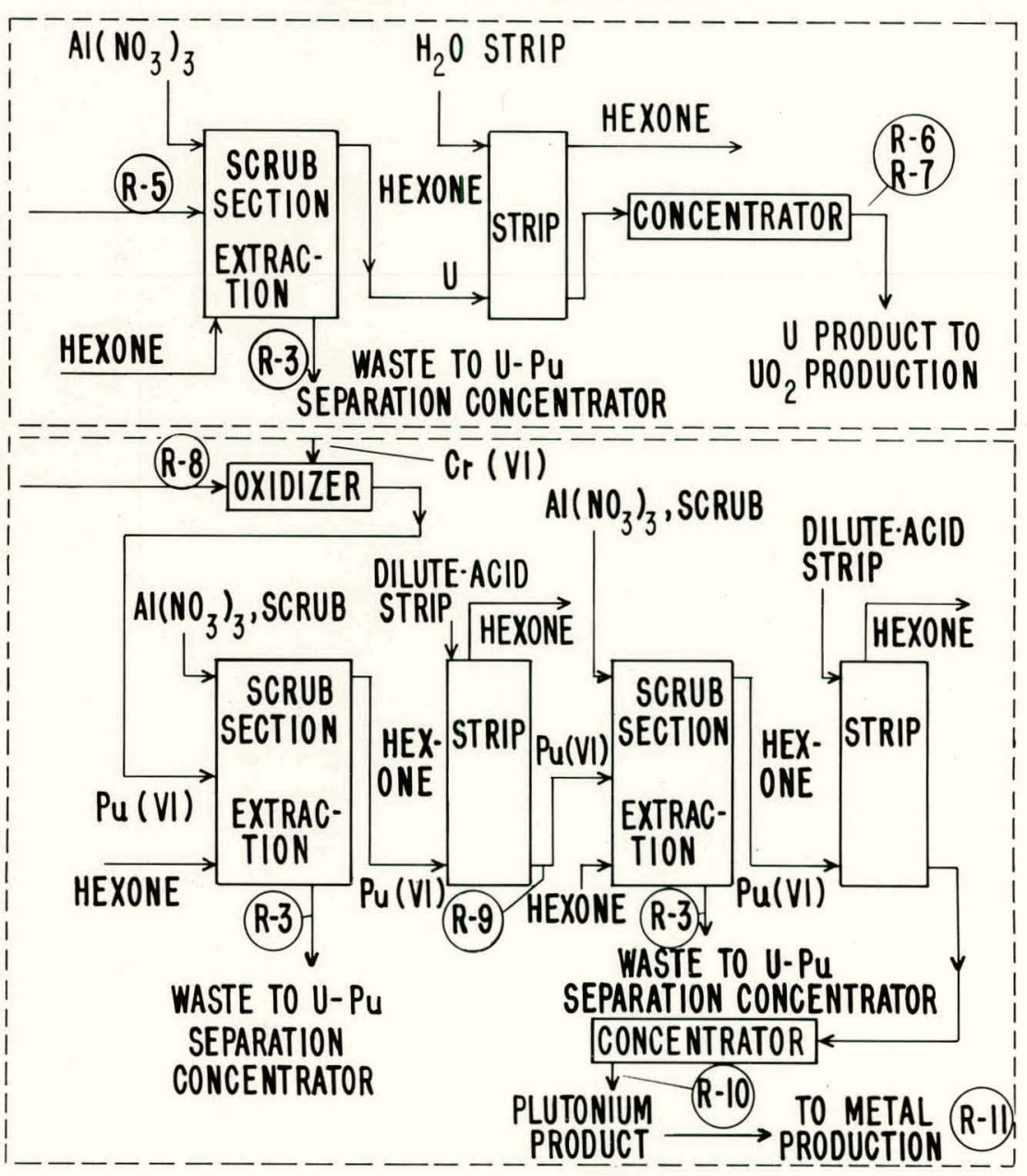

PLUTONIUM RECOVERY 
- FIG. I Flow leet for Redox recovery process.

METZ,C.F.,WATERBURY,G.R. SM $67 . .33$

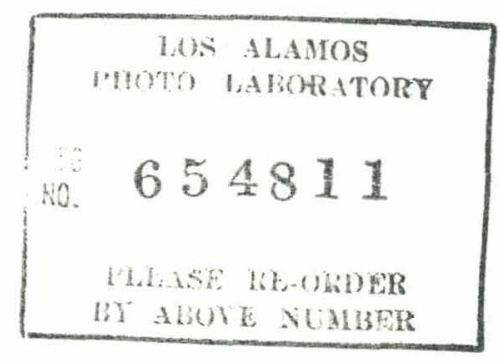




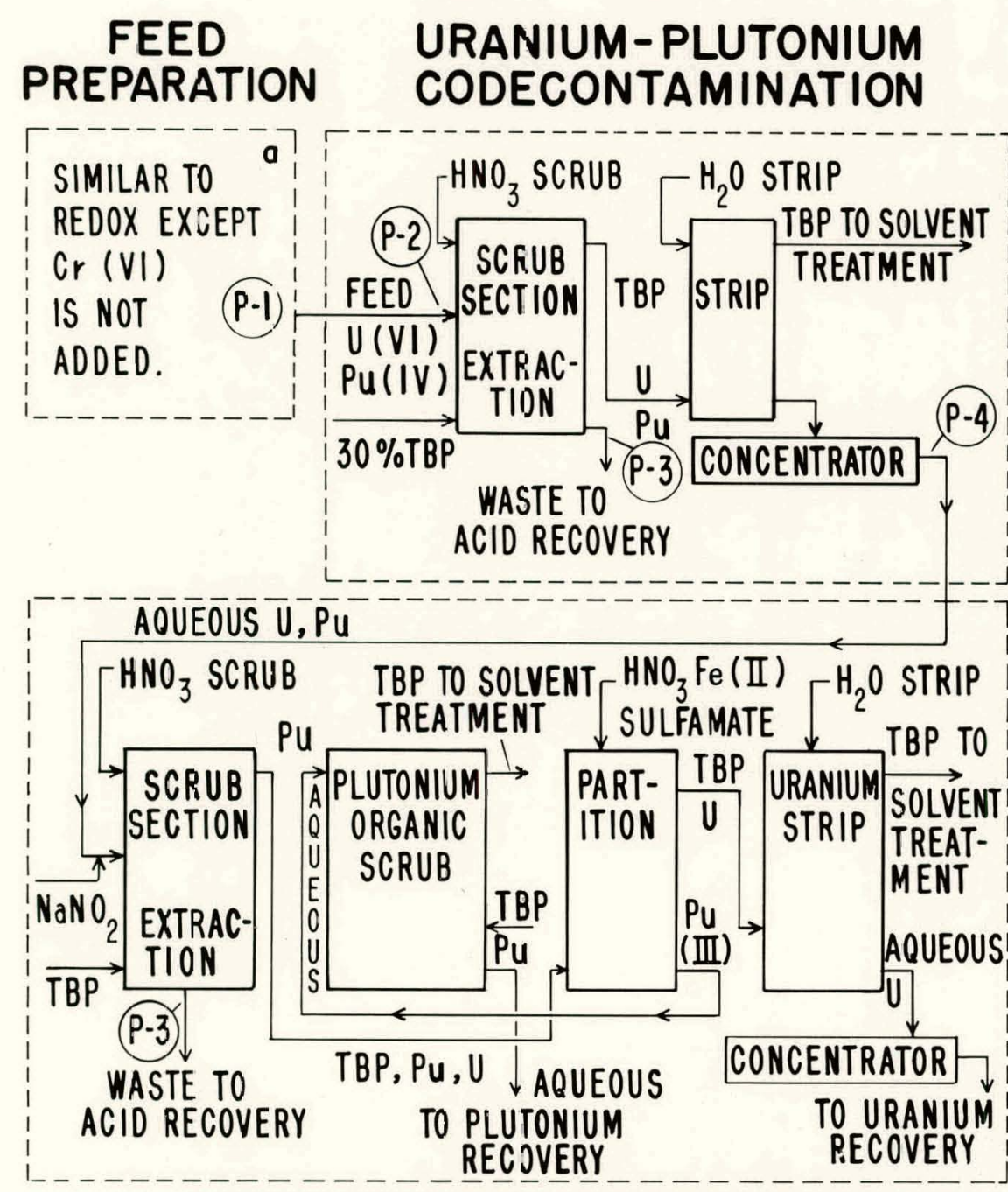

URANIUM-PLUTONIUM PARTITIONING

\section{URANIUM RECOVERY}

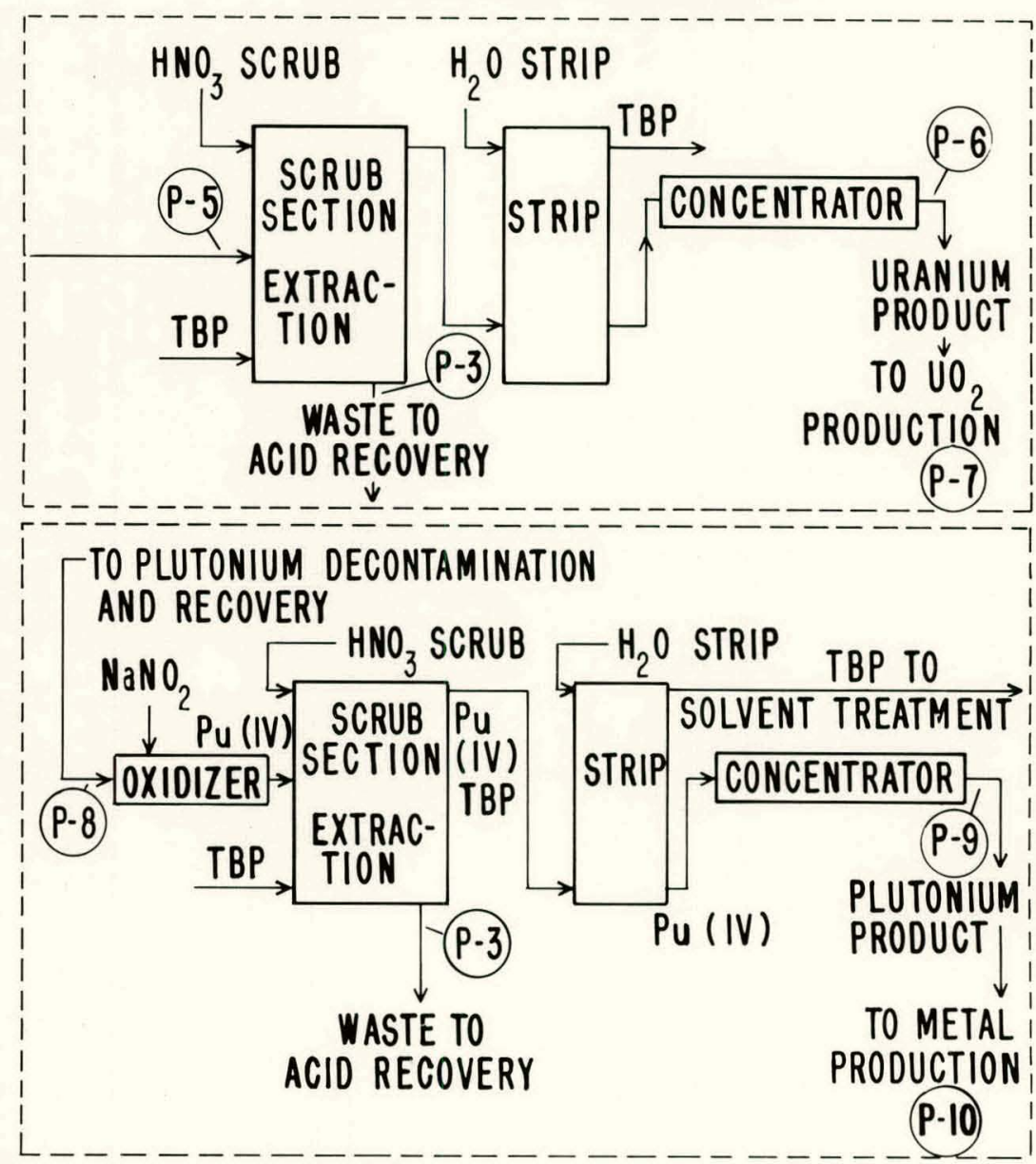

PLUTONIUM RECOVERY 
FIG. 2 Fiow sheet for Purex

icovery process.

METZ,C.F.,WATERBURY,G.R. SM $67 .-33$
FIG. 2 Flow sheat for Pdia recovery process.

METZ,C.F.,WATERBURY,G. $\hat{F}$. SM $67 \cdot \cdot 33$

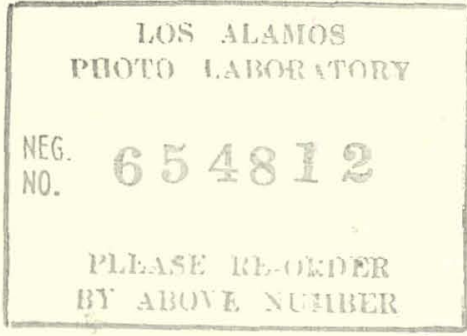

